Journal of Neurocytology 14, 619-635 (1985)

\title{
Differential proliferative responses of cultured Schwann cells to axolemma and myelin-enriched fractions. II. Morphological studies
}

\author{
JAMES H. MEADOR-WOODRUFF* , JUN E. YOSHINO, JOHN W. BIGBEE, \\ BRENDA L. LEWIS and GEORGE H. DEVRIES $†$ \\ Department of Biochemistry, Medical College of Virginia, Box 614 MCV Station, Richmond, Virginia \\ 23298, USA
}

Received 4 January 1985; revised 3 April 1985; accepted 15 April 1985

\begin{abstract}
Summary
Axolemma-enriched and myelin-enriched fractions were prepared from bovine CNS white matter and conjugated to fluorescein isothiocyanate (FITC). Both unlabelled and FITC-labelled axolemma and myelin were mitogenic for cultured rat Schwann cells. Treatment of Schwann cells with the FITC-labelled mitogens for up to $24 \mathrm{~h}$ resulted in two distinct morphological appearances. FITC-myelin-treated cells were filled with numerous round, fluorescent-labelled intracellular vesicles, while FITC-axolemma-treated cells appeared to be coated with a patchy, ill-defined fluorescence, primarily concentrated around the cell body but extending onto the cell processes. These observations were corroborated under phase microscopy. Electron microscopy revealed multiple, membrane-bound, membrane-containing phagosomes within myelin-treated cells and to a far lesser extent in axolemma-treated cells. The effect on the expression of the myelin-mediated and axolemma-mediated mitogenic signal when Schwann cells were treated with the lysosomal inhibitors, ammonium chloride and chloroquine, was evaluated. The mitogenicity of myelin was reduced $70-80 \%$ by these agents whereas the mitogenicity of axolemma was not significantly altered under these conditions. These results suggest that axolemma and myelin stimulate the proliferation of cultured Schwann cells by different mechanisms. Myelin requires endocytosis and lysosomal processing for expression of its mitogenic signal; in contrast, the mitogenicity of axolemma may be transduced at the Schwann cell surface.
\end{abstract}

\section{Introduction}

Schwann cells are known to proliferate in vivo during both neural development (Asbury, 1967; Martin \& Webster, 1973, Terry et al., 1974) and Wallerian degeneration (Fisher \&

*Present address: Department of Psychiatry, University of Michigan Hospitals, Ann Arbor, Michigan 48109, USA.

tTo whom all correspondence should be addressed.

$0300-4864 / 85 \$ 03.00+.12$ (C) 1985 Chapman and Hall Ltd. 
Turano, 1963; Bradley \& Asbury, 1970; Thomas, 1970; Romine et al., 1976). The mechanism of the induction of these proliferative responses has not been elucidated, although each may be mediated by a separate process (Salzer \& Bunge, 1980).

Numerous agents have been shown to be mitogenic for cultured Schwann cells, including axolemma-enriched fractions from both the PNS and CNS (DeVries et al., 1982, 1983b), neurites from dorsal root ganglia (Salzer et al., 1980a, b), pituitary-derived glial growth factor (Raff et al., 1978a; Brockes et al., 1981), cyclic AMP (Raff et al., 1978b) and cholera toxin (Raff et al., 1978a, b). Myelin has also been shown to be mitogenic for Schwann cells (DeVries et al., 1982). Characterization of the neurally-derived mitogens has suggested that they are surface proteins (Salzer et al., 1980b) and require direct contact with the Schwann cell to exert their mitogenic effect (Wood \& Bunge, 1975; Salzer et al., 1980b).

In this report, we demonstrate that the mitogenic signals of axolemma-enriched fractions and myelin preparations are mediated by two distinct pathways. Myelin expresses its mitogenic signal only after endocytosis and lysosomal processing by the cultured Schwann cells. In contrast, the mitogenicity of the axolemma-enriched fraction may be transduced at the Schwann cell surface.

These morphological observations support our previous biochemical evidence for two separate mechanisms for the transduction of the two mitogenic signals by cultured Schwann cells (Yoshino et al., 1984). Previously, it has been suggested that the proliferative response of Schwann cells seen in vivo during Wallerian degeneration and neural development may also be mediated by two different signals (Salzer \& Bunge, 1980). The present report supports this suggestion. The demonstration of two distinct pathways for expression of mitogenic signals may represent in vitro models of these two in vivo phenomena in which Schwann cell proliferation is observed.

\section{Materials and methods}

Preparation of Schwann cells

Schwann cells were prepared by the method of Brockes et al. (1979). Briefly, sciatic nerves were removed from 2-3 day rat pups. The nerves were treated with trypsin (Type IX, Sigma) and collagenase (Type III, Worthington), and were then triturated with a pasteur pipette and filtered through 209 Micron Nitex (Tetko, Inc.). The cells were collected by centrifugation and resuspended in Dulbecco's Modified Eagle's Medium (DME) (GIBCO) with 10\% foetal calf serum (Sterile Systems). The cells were plated in $100 \mathrm{~mm}$ glass dishes at a density of $3-4.5 \times 10^{6}$ cells per dish. After $24 \mathrm{~h}$, cytosine arabinoside was added to inhibit fibroblast proliferation (final concentration $=10^{-5} \mathrm{M}$ ). The medium was replaced without cytosine arabinoside after $72 \mathrm{~h}$. After three additional days, the cells were treated with rabbit complement (Cappel Labs) and anti-Thy 1.1 (New England Nuclear), an antibody that is directed against an antigen found on fibroblasts but not Schwann cells, in order to eliminate remaining fibroblasts by complementmediated lysis. The cells were then collected by centrifugation and plated onto $12 \mathrm{~mm}$ glass coverslips at a density of $3-5 \times 10^{4}$ cells per slip. These procedures resulted in cultures that were greater than $99.5 \%$ Schwann cells, as determined by phase microscopy. 
Preparation of axolemma and myelin-enriched fractions

Axolemma and myelin-enriched fractions were prepared as previously reported (DeVries et al., $1978 ; 1983 \mathrm{a}, \mathrm{b}$ ). Briefly, $1 \mathrm{~g}$ of bovine cervical cord white matter was gently homogenized in buffered salt-sucrose media and centrifuged to obtain a floating layer of myelinated axons which were mechanically and osmotically shocked. The shocked myelinated axon suspension ( $3 \mathrm{ml}$ ) was applied to a $34 \mathrm{ml} 10-40 \%$ linear sucrose gradient and centrifuged at $82500 \times \mathrm{g}$ for $18 \mathrm{~h}$. The gradient was fractionated, and sucrose concentrations of each fraction were determined. Fractions with sucrose concentrations of $17-20 \%$ were pooled as myelin-enriched fractions, and fractions of $27-32 \%$ sucrose concentration were pooled as axolemma-enriched fractions. The sucrose used in all preceding steps contained $0.02 \%(\mathrm{w} / \mathrm{v})$ azide. These fractions were then either treated with fluorescein isothiocyanate (FITC) (see below), or were centrifuged at $82500 \times g$ for $1 \mathrm{~h}$ and the pellet resuspended in 1-2 $\mathrm{ml}$ of sterile $138 \mathrm{~mm} \mathrm{NaCl}, 5.4 \mathrm{~mm} \mathrm{KCl}, 1.1 \mathrm{~mm} \mathrm{Na} 2 \mathrm{PO}_{4}, 1.1 \mathrm{~mm} \mathrm{KH}_{2} \mathrm{PO}_{4}$ and $22 \mathrm{~mm}$ dextrose, $\mathrm{pH} 7.0$ (saline I) to a concentration of approximately $1 \mathrm{mg}$ protein $\mathrm{ml}^{-1}$, and frozen at $-20^{\circ} \mathrm{C}$ in small aliquots. Protein was determined by the method of Bradford (1976), with $\gamma$-globulin as the standard.

\section{Preparation of FITC-labelled membranes}

Pooled membrane fractions as prepared above were conjugated to FITC as outlined by Pearse

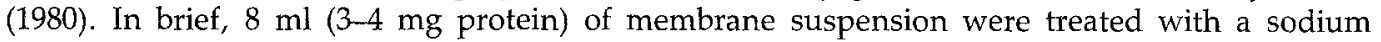
carbonate buffer (final concentration $=0.075 \mathrm{M}$; pH 9.0) at $4^{\circ} \mathrm{C}$. Solid FITC powder $(1 \mathrm{mg}$ ) was added, and the mixture stirred overnight at $4^{\circ} \mathrm{C}$. An equal volume of isotonic saline was added and the resulting suspension was centrifuged at $82500 \times g$ for $1 \mathrm{~h}$. The resulting pellet was resuspended in 1-2 $\mathrm{ml}$ sterile saline $\mathrm{I}$ to a concentration of $1-2 \mathrm{mg}$ protein $\mathrm{ml}^{-1}$, and frozen at $-20^{\circ} \mathrm{C}$ in $100-200 \mu \mathrm{l}$ aliquots.

\section{Light level radiography}

Schwann cell-plated coverslips were contained in Linbro plates which had 24 individual wells; each well contained $500 \mu \mathrm{l}$ DME plus $10 \%$ foetal calf serum. Mitogens and, in some experiments, sterile-filtered solutions of ammonium chloride $\left(\mathrm{NH}_{4} \mathrm{Cl}\right)$ or chloroquine were added $24 \mathrm{~h}$ after plating. These agents were diluted in sterile DME plus $10 \%$ foetal calf serum to the desired concentrations. After a further $24 \mathrm{~h}, 1.5 \mu \mathrm{Ci}$ of $\left[{ }^{3} \mathrm{H}\right]$ thymidine $\left(19.3 \mathrm{Ci} \mathrm{mmol}^{-1}\right.$, New England Nuclear) were added. The total final volume was $712.5 \mu \mathrm{l}$, unless otherwise noted. The cells were fixed in $2 \%$ paraformaldehyde $48 \mathrm{~h}$ after the addition of thymidine, then dehydrated in graded alcohols and mounted onto slides. The slides were dipped in NTB-2 emulsion (Eastman Kodak) which was diluted 1:2 in water, then dried and stored in the dark at $4^{\circ} \mathrm{C}$ for $3-4$ days. They were developed, fixed, and stained with haematoxylin and eosin. A minimum of 500 cells were evaluated on each coverslip and the labelling index was calculated (labelled cells/total cells $\times 100$ ). A cell was considered labelled if more than 20 grains were observed over the nucleus. This method has been previously described (DeVries et al., 1982, 1983a).

\section{Light level microscopy}

Fluorescence and phase contrast micrographs were obtained on a Zeiss photomicroscope III using the built-in automatic camera. Kodak Tri- $X$ film exposed at 2000 ASA was used for photographs. Fluorescent images were obtained using a halogen light source, an exciter filter (450-490 nm), diachromic mirror $(510 \mathrm{~nm})$ and barrier filter $(520 \mathrm{~nm})$ incorporated into the microscope.

\section{Electron microscopy}

For electron microscope studies, Schwann cells were plated onto $12 \mathrm{~mm}$ Aclar discs at a density of 
$5.0 \times 10^{4}$ cells per disc. The cells were treated with either axolemma, myelin ( $14 \mu \mathrm{g}$ protein $\mathrm{ml}^{-1}$ of media) or media alone. After $24 \mathrm{~h}$, the cultures were rinsed with saline I, fixed for $2 \mathrm{~h}$ in $2 \%$ glutaraldehyde in saline I and post-fixed in $2 \%$ aqueous osmium tetroxide for $1 \mathrm{~h}$. The cells were dehydrated with graded alcohols, infiltrated and embedded directly in PolyBed 812 epoxy resin. During the polymerization of the resin, the discs were placed in flat embedding mold with the cell side down. Areas of the disc containing cells were cut out and mounted on lucite stubs, then trimmed and sectioned en face with a Sorvall Porter-Blum MT-2 ultramicrotome. Silver-gold sections were stained with uranyl acetate and lead citrate and examined with a Hitachi HU-12 electron microscope.

\section{Other methods}

Polyacrylamide gel electrophoresis was performed as previously described by Bigbee et al. (1985); $50 \mu \mathrm{g}$ of protein per sample was subjected to electrophoresis. Rat liver microsomes were prepared by the method of Neville (1968).

\section{Statistical analyses}

Student's $t$-test was used for all statistical analyses, with $P<0.05$ used to define significance.

\section{Results}

Characterization of FITC-conjugated membranes

To ensure that FITC-conjugation had not altered the activity of the axolemma and myelin-enriched fractions, the mitogenic activity of both unlabelled and FITC-

Table 1. Effect of FITC-conjugation on the mitogenicity as measured by radioautography of bovine CNS axolemma and myelin-enriched fractions.

\begin{tabular}{lr}
\hline Sample & {$\left[{ }^{3} \mathrm{H}\right]$ thymidine-labelled nuclei $(\%)$} \\
\hline Control (no mitogen added) & $1.4 \pm 0.2$ \\
Axolemma & $25.6 \pm 3.9$ \\
FITC-axolemma & $27.6 \pm 1.6$ \\
Myelin & $14.9 \pm 1.0$ \\
FITC-myelin & $12.8 \pm 2.1$ \\
\hline
\end{tabular}

Values reported are mean percentages of two slides (500 cells counted each) \pm S.E.M. Final mitogen concentration $=14 \mu \mathrm{g}$ protein $\mathrm{ml}^{-1}$ of media.

Fig. 1. Schwann cells following exposure to FITC-myelin. (A) Fluorescence microscopy; (B) phase microscopy. Schwann cells were plated onto glass coverslips at a density of 28000 cells per slip, and were treated with FITC-myelin $\left(14 \mu \mathrm{g} \mathrm{ml}^{-1}\right)$ in DME $+10 \%$ foetal calf serum for $24 \mathrm{~h}$. The slips were rinsed once, placed on a glass slide and examined. Note multiple, sharply outlined, discrete intracellular inclusions. Scale bar $=5 \mu \mathrm{m} . \times 1800$. 

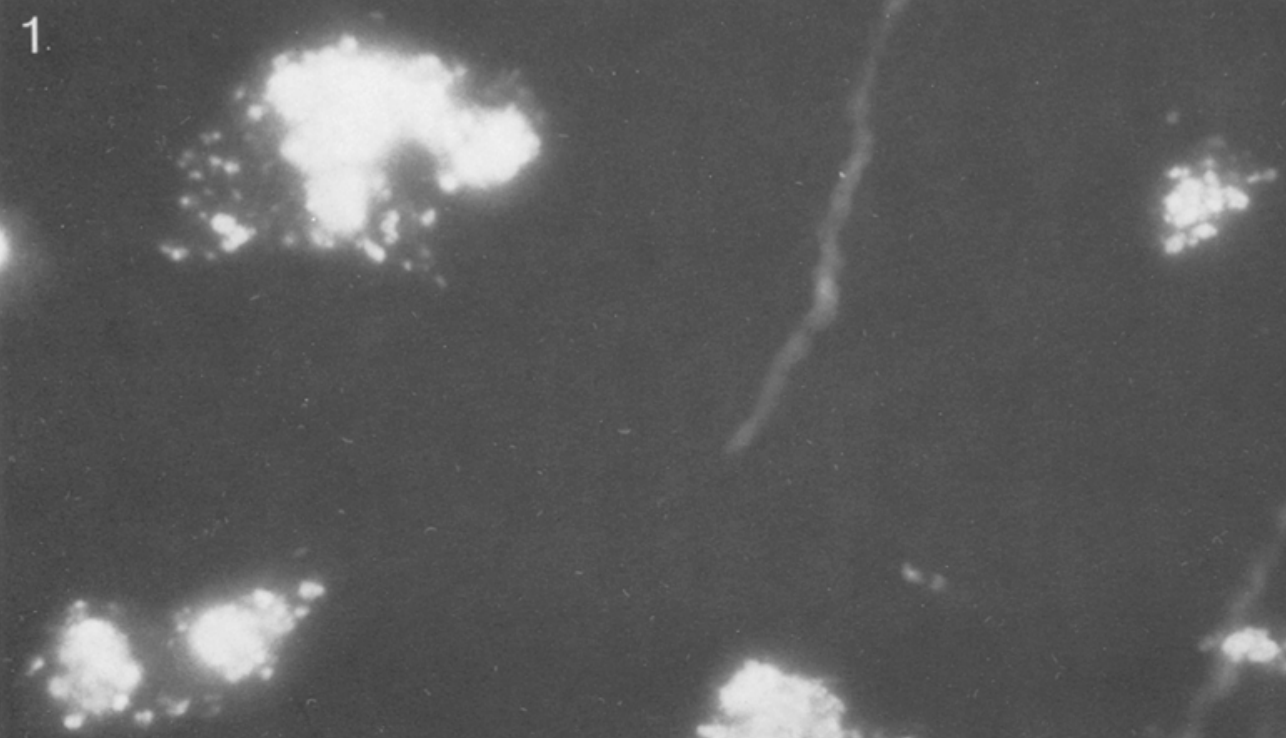

A
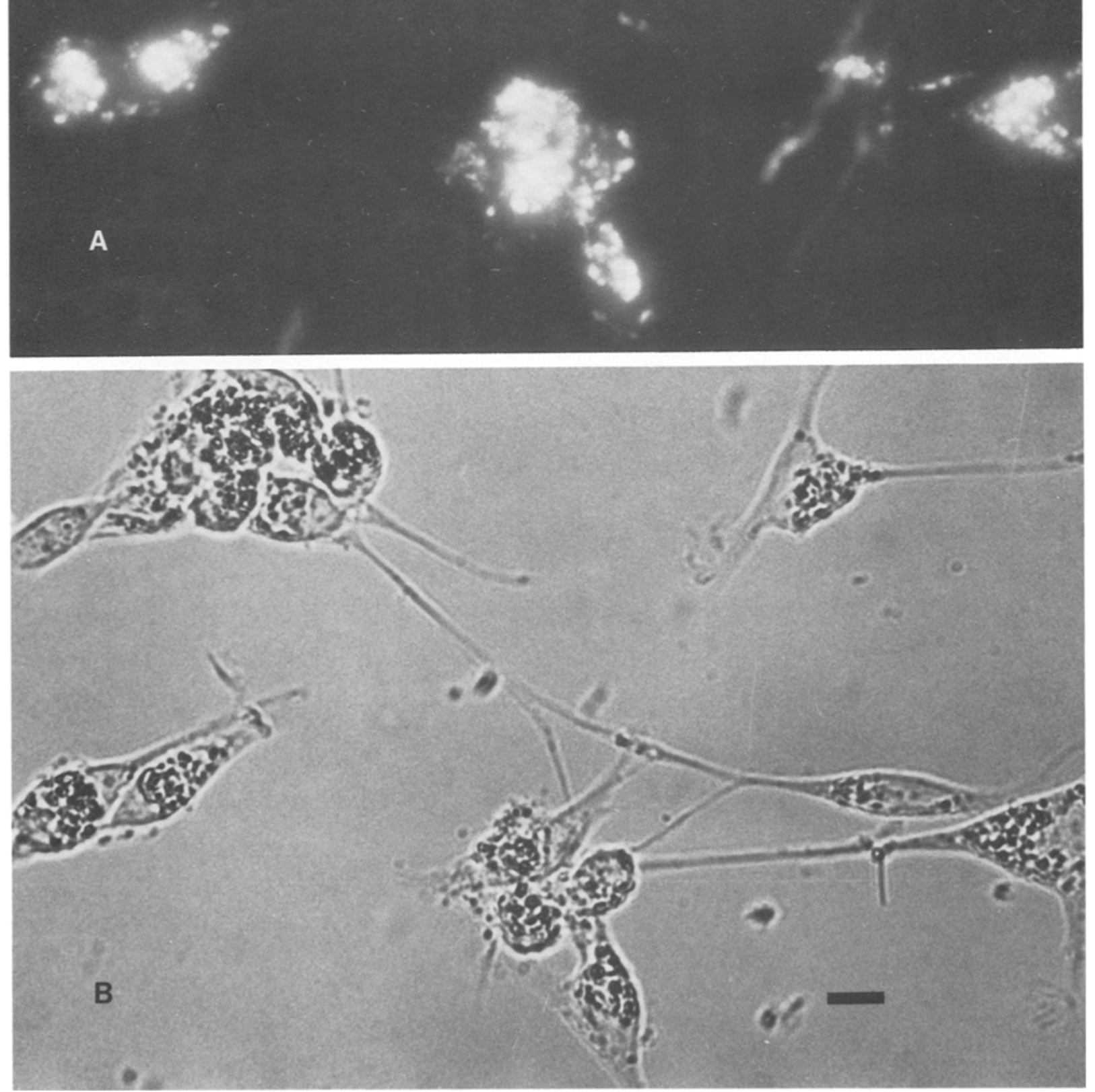
conjugated membranes was determined by their ability to promote $\left[{ }^{3} \mathrm{H}\right]$ thymidine incorporation into Schwann cells as measured by light-level radioautography (DeVries $e t$ al., 1982, 1983a). As shown in Table 1, the labelling indices ranged from $14.9 \%$ for myelin to $25.6 \%$ for axolemma; no statistically significant difference in mitogenicity was noted following FITC-treatment of the membranes.

Rat liver microsomes have been previously shown not to be mitogenic for cultured Schwann cells (DeVries et al., 1983a). Rat liver microsomes were conjugated with FITC and were found to have a labelling index of $1.7 \%$, i.e. not significantly different from control wells with no added mitogen (data not shown).
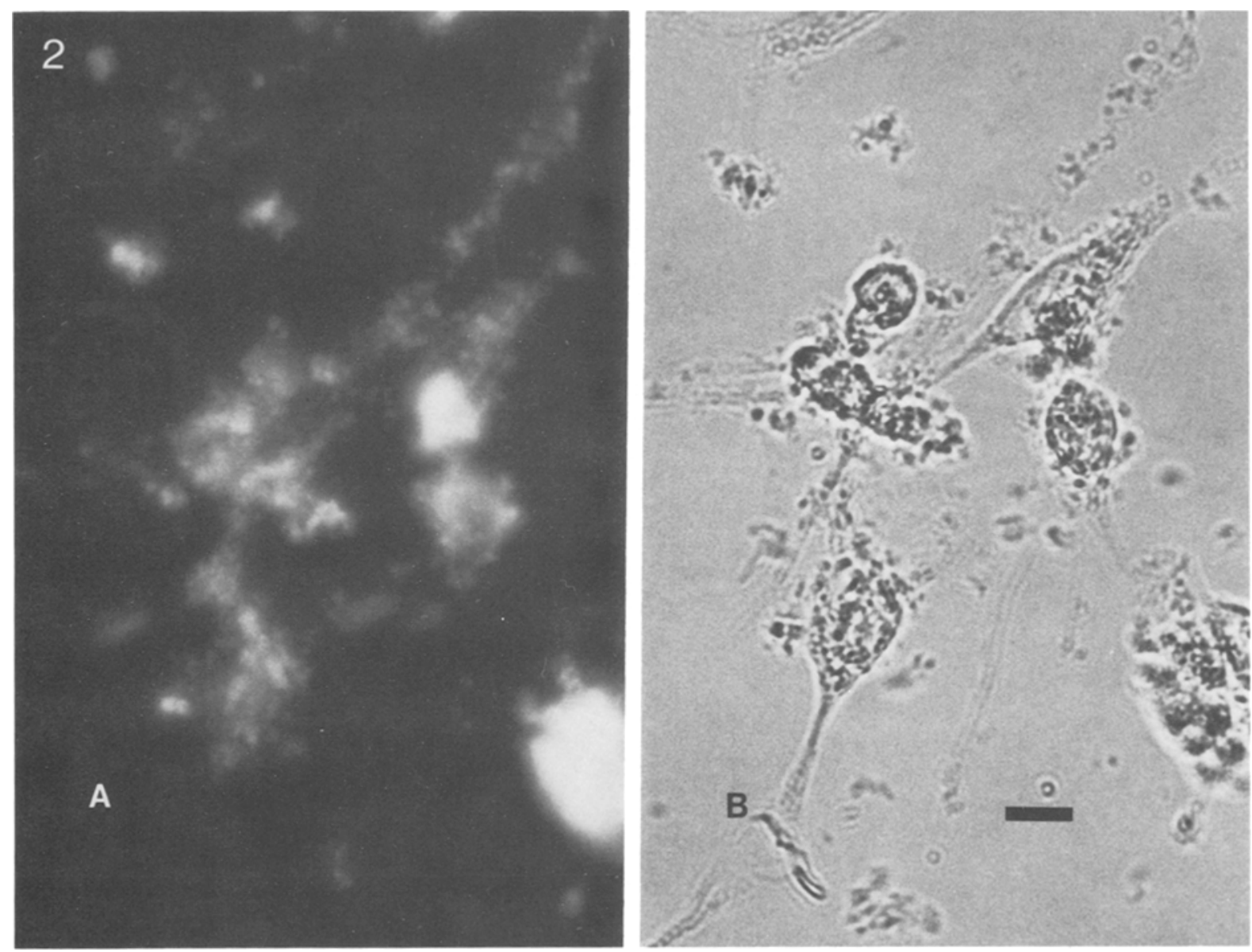

Fig. 2. Schwann cells foliowing exposure to FITC-axolemma. (A) Fluorescence; (B) phase microscopy. Treated as cells in Fig. 1, except with labelled axolemma instead of myelin. Note irregular, poorly-defined areas of labelled membrane tending to cluster around cell body. Scale bar $=5 \mu \mathrm{m} . \times 1800$. 
To determine which components of the axolemma and myelin preparations had been labelled with FITC, samples of both were electrophoresed on polyacrylamide gels. Fluorescence was evenly distributed among the separated polypeptides and the lipids which migrated with the dye front (data not shown), indicating that the conjugation procedure resulted in uniform and nonspecific labelling of all the molecular components of axolemma and myelin.

Nature of the interaction between Schwann cells and FITC-labelled membranes Exposure of Schwann cells to FITC-labelled axolemma and myelin-enriched fractions resulted in two very different morphological appearances. In cells treated with labelled myelin, there appeared to be numerous sharply circumscribed areas of fluorescence concentrated in the Schwann cell body (Fig. 1A); at least 95\% of the Schwann cells on the coverslip were so labelled. Examination of such cells under phase microscopy (Fig. 1B) revealed that the cells were filled with numerous structures that appeared vacuole-like. It was reasonable to conclude that these areas of fluorescence were indeed intracellular membrane-bound vesicles (phagosomes) for several reasons. First, the areas always appeared to be within the confines of the Schwann cell plasma membrane; if they were labelled membranes adhering to the cell surface, one would expect to see instances where these fluorescent areas would appear to protrude beyond the cell membrane. Second, these areas of fluorescence appeared identical to what has been previously described as intracellular vesicles filled with FITC-labelled proteins in other cell lines (Easty \& Trowell, 1965; Rhodes \& Lind, 1968; Wild, 1970, 1973). Third, various investigators have used electron microscopy to demonstrate membranes in Schwann cell phagosomes during Wallerian degeneration (Satinsky et al., 1964; Holtzman \& Novikoff, 1965; Berner et al., 1973), supporting the contention that Schwann cells can phagocytose myelin.

Schwann cells treated with FITC-labelled axolemma were characteristically different from myelin-treated cells (Fig. 2A, B). Examination with fluorescence microscopy (Fig. 2A) revealed that the axolemma appeared as a highly irregular and ill-defined fluorescent area, with the fluorescence at its highest concentration around the cell body but also continuing well onto the cell processes. The fluorescence was not confined to within the boundary of the cell outline and gave the appearance of membrane fragments coating the exterior of the Schwann cell. At least $95 \%$ of the cells on the coverslip manifested this appearance. Under phase microscopy (Fig. 2B), aggregates of membranes could be observed surrounding and apparently in contact with the Schwann cells, correlating well with the fluorescent image. Areas of fluorescence which had the appearance of the phagosomes previously seen in myelin-treated cells could occasionally be found in axolemma-treated cells.

To determine if either of these phenomena was specific for the given membrane preparation, rat liver microsomes were prepared and conjugated to FITC in the same manner as the axolemma and myelin. When Schwann cells were treated with microsomes at similar concentrations, a pattern similar to that seen in myelin-treated 
cells was observed. Only $20-25 \%$ of the Schwann cells on the coverslip manifested the intracellular inclusions (data not shown), however, and there were substantially fewer phagosomes per labelled cell than in the case of myelin-treated cells. This is in agreement with a previous report (Salzer et al., 1980a) in which Schwann cells were observed to phagocytose various membranes nonspecifically.

A control preparation of Schwann cells was treated with a solution of FITC only. Under the conditions used for observing the membrane-treated cells, FITC was not observed to interact with the cells at all.

\section{Electron microscopy of mitogen-treated Schwann cells}

To determine if the areas of fluorescence seen in FITC-myelin treated cells were indeed intracellular and to attempt to study further the nature of the axolemma-Schwann cell interaction, mitogen-treated Schwann cells were examined by electron microscopy. In axolemma-treated cells unilamellar membrane vesicles of various sizes were observed in close proximity to Schwann cells (Fig. 3B), but only rarely were they observed to be in direct contact with the cell. The interaction of these vesicles that was seen by light-level microscopy may have been disrupted by processing for electron microscopy, or the points of contact may have been out of the plane of the thin sections taken for electron microscopy.

Axolemma-treated cells contained occasional intracellular phagosomes (data not shown). In contrast to the axolemma-treated Schwann cells, myelin-treated cells displayed numerous membrane-bound vesicles containing electron-dense membranes (Fig. 4A). At higher magnification (Fig. 4B), these dense membranes were observed to be multilamellar. The periodicity between major dense lines measured 11-35 nm which agreed well with the reported periodicity of 12-18 $\mathrm{nm}$ for the myelin membrane in situ (Raine, 1977). Control cells with no mitogen exposure (Fig. 3A) contained no membrane-bound vesicles. The morphological characteristics were similar to those recently reported for cultured Schwann cells (Fields \& Raine, 1982).

\section{Effect of lysosomal inhibitors on mitogenic signals}

To determine if the phagocytosis of myelin and axolemma was associated with their mitogenicity, Schwann cells were treated with axolemma- and myelin-enriched fractions in the presence and absence of the lysosomal inhibitors, $\mathrm{NH}_{4} \mathrm{Cl}$ and chloroquine. These agents appear selectively to elevate $\mathrm{pH}$ within the lysosome while not affecting cytoplasmic $\mathrm{pH}$ (Poole \& Ohkuma, 1981), thus diminishing lysosomal enzyme function. These agents have been studied in numerous cell systems and have been shown to

Fig. 3. Electron micrographs of mitogen-treated Schwann cells. (A) Control cell. Note normal Schwann cell ultrastructure and absence of phagosomes. Scale bar $=5 \mu \mathrm{m} . \times 7000$. (B) Axolemma-treated cells. Note numerous membrane fragments surrounding cells, and membrane in contact with the cell (arrow). Scale bar $=5 \mu \mathrm{m} . \times 5600$. 

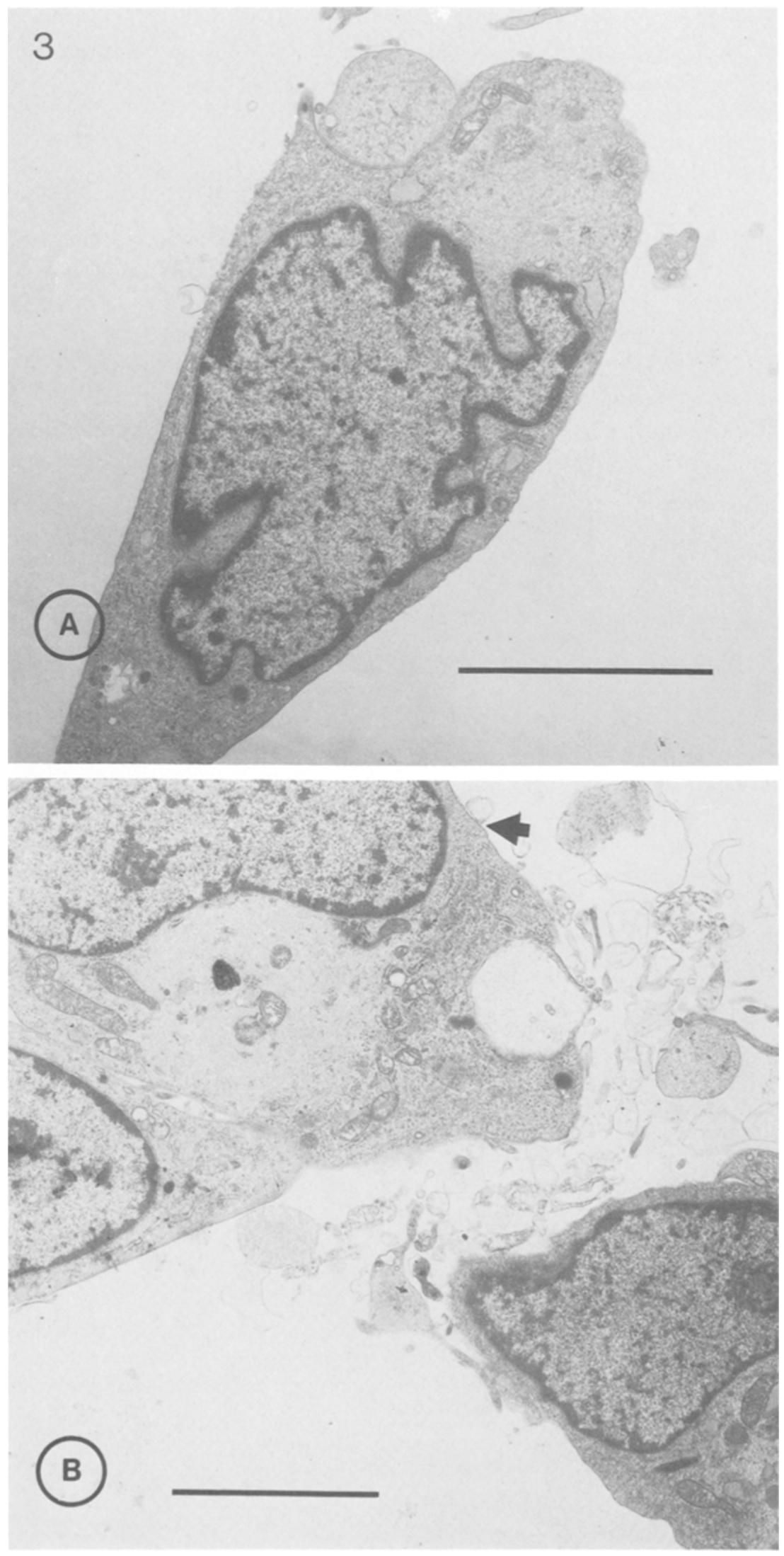
inhibit protein degradation (Seglen, 1975; Seglen \& Reith, 1976; Rote \& Rechsteiner, 1983) and glycosaminoglycan turnover (Glimelius et al., 1977). They have been implicated in inhibiting endocytosis as well as lysosomal function (Sandvig et al., 1979; Tietze et al., 1980).

The results of these experiments are summarized in Figs 5 and 6. Increasing doses of $\mathrm{NH}_{4} \mathrm{Cl}$ (Fig. 5) caused a steady and significant reduction of $\left[{ }^{3} \mathrm{H}\right]$ thymidine incorporation into Schwann cells in myelin-treated preparations. At doses as low as $6 \mathrm{mM} \mathrm{NH}_{4} \mathrm{Cl}$, the myelin mitogenic signal as measured by radioautography was reduced by $44 \%$ ( $P<$ 0.001 ). At $12 \mathrm{~mm}$ (the highest dose tested), the myelin mitogenic signal was reduced by $71 \%(P<0.001)$. Schwann cells treated with axolemma-enriched fraction showed no significant decrease in the labelling index when treated with concentrations of $\mathrm{NH}_{4} \mathrm{Cl}$ which significantly inhibited the mitogenic response of cultured Schwann cells to myelin.

Similar results were obtained when axolemma and myelin-treated Schwann cells were subjected to chloroquine (Fig. 6). No significant change in the level of mitogenic activity was noted when axolemma-treated cells were exposed to chloroquine. Myelin-treated cells showed a significant $(P<0.01)$ reduction in labelled nuclei at chloroquine concentrations as low as $4 \mu \mathrm{M}$, with a $73 \%$ decrease in mitogenic activity at $6 \mu \mathrm{M}(P<$ 0.001). Control preparations, i.e. Schwann cells treated with or without the lysosomal inhibitors in the absence of axolemma or myelin, consistently had a labelling index of less than $0.2 \%$.

Examination of Fig. 6 suggests that the axolemma-treated cells experience a reduction in mitogenic intensity as chloroquine concentration increases. To determine if this apparent trend ever becomes significant, higher concentrations of chloroquine were applied in a separate experiment. A chloroquine concentration of $14 \mu \mathrm{M}$ caused a highly significant $(P<0.001) 60 \%$ decrease in the myelin mitogenic signal, from $13.7 \pm 1.4 \%$ to $5.7 \pm 0.7 \%$; the axolemma signal was only reduced from $17.7 \pm 2.4 \%$ to $14.5 \pm 1.6 \%$ (not significant). Higher concentrations of chloroquine were cytotoxic for the Schwann cells.

\section{Discussion}

We have demonstrated that axolemma-enriched and myelin-enriched fractions stimulate cultured Schwann cell proliferation by different mechanisms. Myelin was endocytosed, contained in vacuoles (phagosomes) and required lysosomal processing by the Schwann cell for expression of its mitogenic activity. Axolemma, however, appeared under

Fig. 4. Myelin-treated cell. Note numerous phagosomes containing densely-stained membranes. Scale bar $=5 \mu \mathrm{m} . \times 4900$. (B) Enlargement of (A). Arrows indicate membraneous phagosome contents having an $11-35 \mathrm{~nm}$ periodicity. Note large number of lysosomes in cytoplasm (L). Scale bar $=1 \mu \mathrm{m} . \times 21120$. 


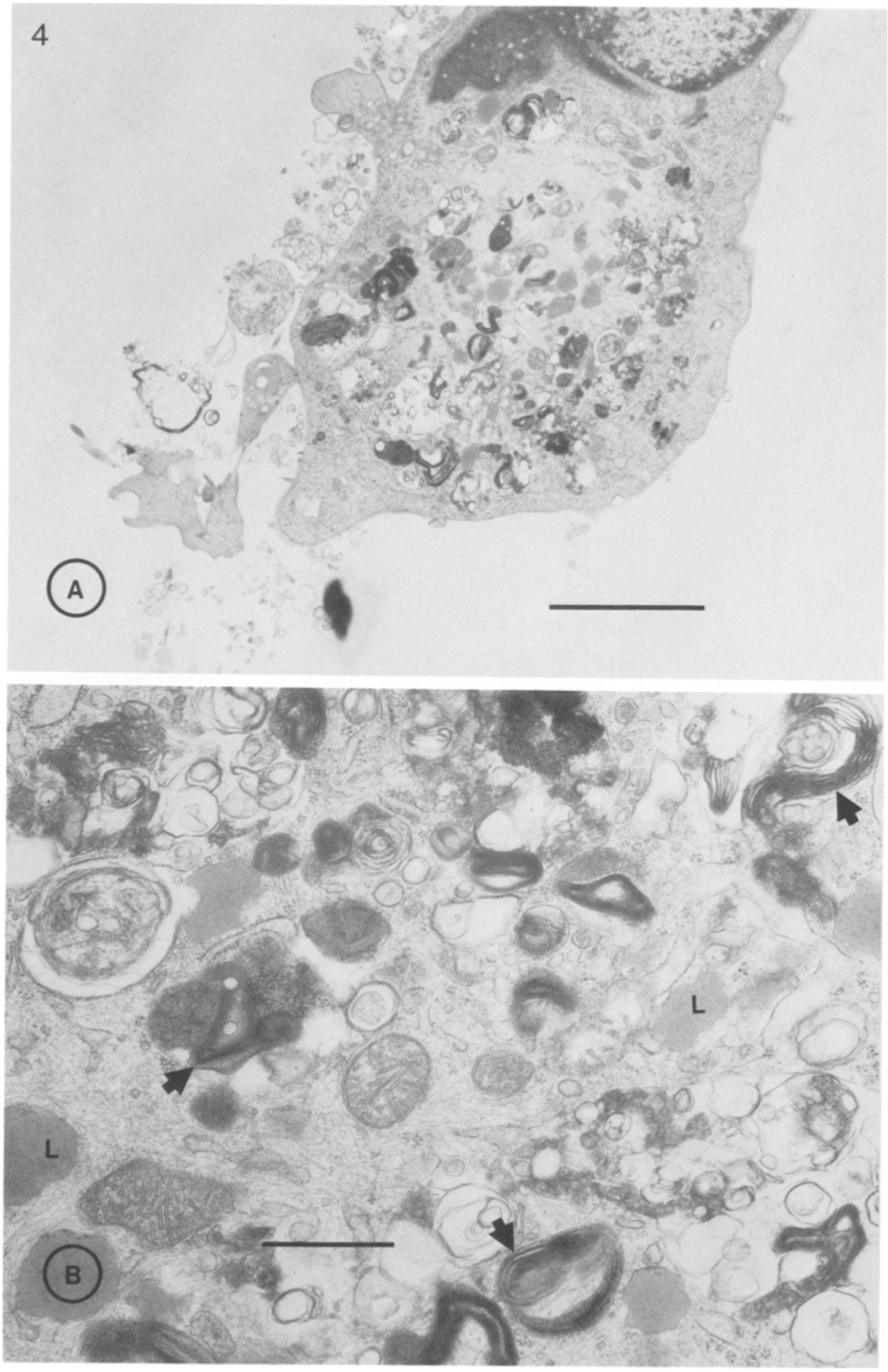




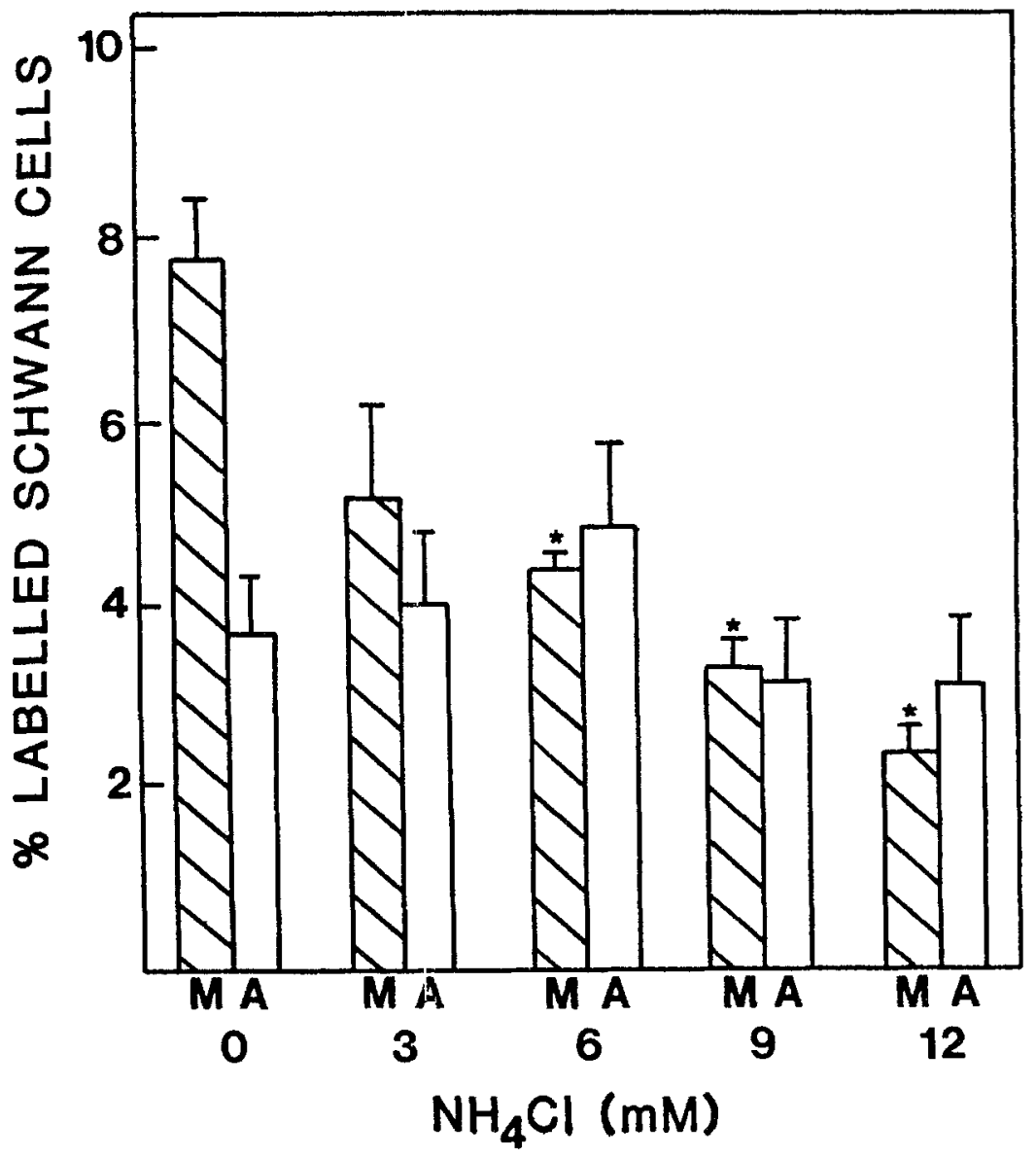

Fig. 5. Effect of ammonium chloride on $\left[{ }^{3} \mathrm{H}\right]$ thymidine labelling of stimulated Schwann cells. Schwann cells were plated on glass coverslips at a density of 38000 cells per slip, and were processed for radioautography as described in text. Axolemma (A) and myelin (M) concentrations were $7 \mu \mathrm{g} \mathrm{ml}^{-1}$. Results are expressed as the means \pm s.E.M. * indicates $P<0.01$ when compared to control $\left(\mathrm{NH}_{4} \mathrm{Cl}=0\right)$.

light-level microscopy to interact with Schwann cells at the cell surface for prolonged periods. Lysosomal processing was not required for the expression of the mitogenicity of axolemma-enriched fractions, even though electron microscopy showed that some endocytosis had occurred.

Phagocytosis of membranes did not appear to be a stimulus for mitogenicity, in agreement with a previous report (Salzer et al., 1980b), inasmuch as liver microsomes were not mitogenic. Lysosomal processing, however, did appear to be a specific requirement for the expression of the mitogenic activity of myelin, as inhibition of lysosomal function diminished the mitogenicity of myelin but spared that of axolemma. 


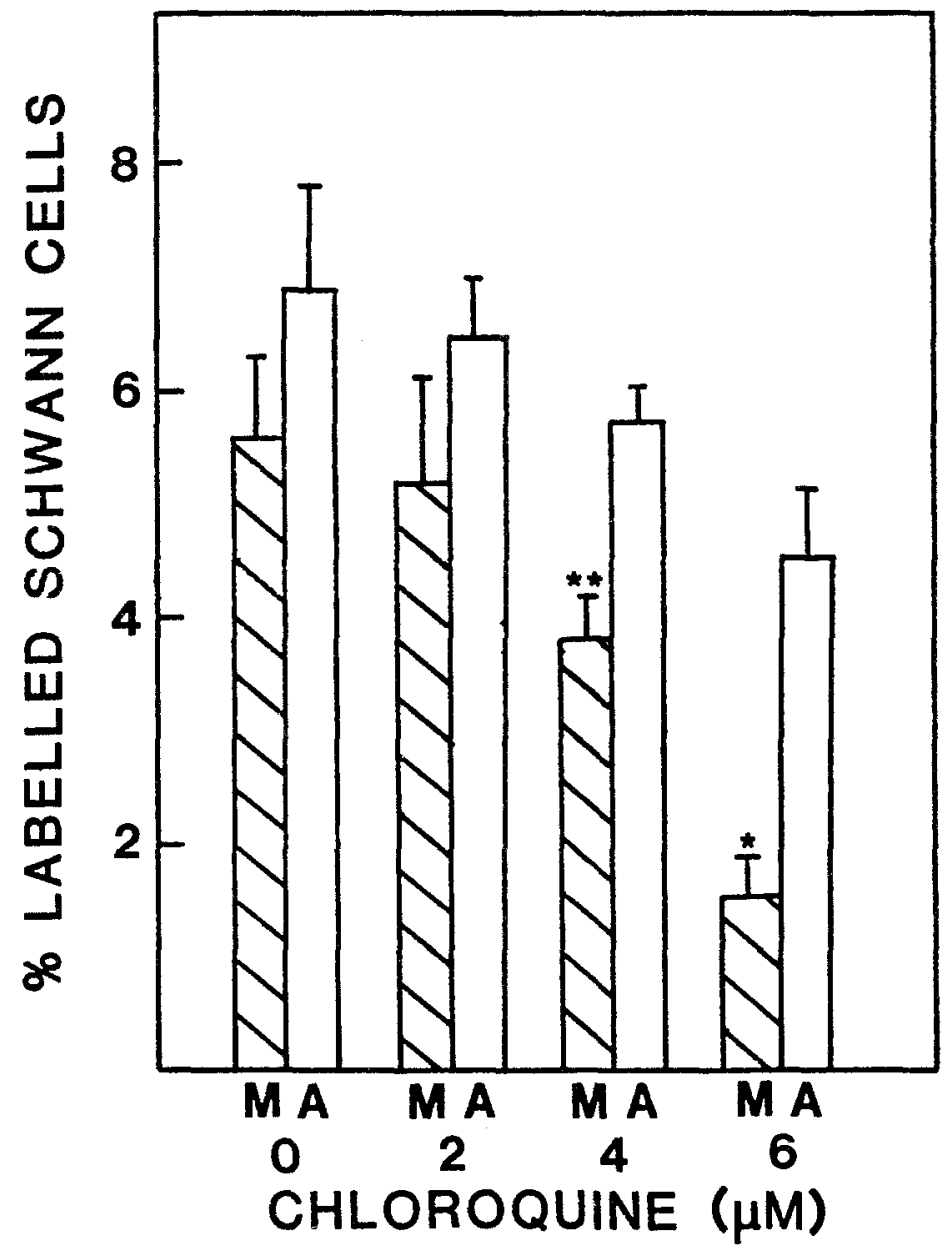

Fig. 6. Effect of chloroquine on $\left[{ }^{3} \mathrm{H}\right]$ thymidine labelling of stimulated Schwann cells. Cells were plated on coverslips at a density of 40000 cells per slip, and were processed for radioautography as outlined in the text. Axolemma (A) and myelin (M) concentrations were $7 \mu \mathrm{g} \mathrm{ml}^{-1}$. Results are expressed as the means of at least five fields of greater than 100 cells \pm S.E.M. $* *, P<0.001 ; *, P<$ 0.01 when compared to control (chloroquine $=0$ ).

The reduction by $71-73 \%$ of the myelin mitogenic signal was in close agreement with reports of lysosomal inhibition in other systems. Lysosomal protein degradation has been reported to be decreased by up to $75-80 \%$ by similar doses of chloroquine and $\mathrm{NH}_{4} \mathrm{Cl}$ (Seglen, 1975; Seglen \& Reith 1976; Rote \& Rechsteiner, 1983); glycosaminoglycan turnover in glial cells has been reported to be altered by $67 \%$ (Glimelius et al., 1977).

The observed endocytosis and lysosomal processing of myelin as a stimulus for Schwann cell proliferation is consistent with observations that have been made during Wallerian degeneration. Schwann cells proliferate during degeneration with a maximal 
response by the third day following lesioning (Friede \& Johnstone, 1967). Concomitant with Schwann cell mitosis, phagocytosis of debris including myelin is observed (Satinsky et al., 1964). The source of the phagocytic cells seen in vivo has been the subject of controversy, but most recent investigations have indicated that the Schwann cell itself ingests the myelin (Holtzman \& Novikoff, 1965; Salzer et al., 1980b). Further, several investigators have implicated lysosomal activation during degeneration by measuring various marker enzymes (Fisher \& Turano, 1963; Holtzman \& Novikoff, 1965).

Our results indicate that myelin is a stimulus for Schwann cell mitosis, and the lysosomal function must be intact for expression of the mitogenic signal. These findings are consistent with those of other investigators who suggested that the breakdown of myelin by cultured Schwann cells may be the trigger for mitosis (Salzer \& Bunge, 1980). Phagocytosis and lysosomal processing of myelin debris may be required during Wallerian degeneration in order for Schwann cells to proliferate. On the other hand, Beuche \& Friede (1984) concluded that Schwann cell proliferation characteristic of Wallerian degeneration did not occur when non-resident cells (i.e. macrophages) were excluded from the site of the lesion. This conclusion was based on the observation of mouse peripheral nerves which had been transplanted into Millipore diffusion chambers (containing pores which either excluded or allowed infiltration of non-resident cells) which were implanted into the peritoneal cavity. These disparate findings may be reconciled by considering that the present study utilized Schwann cells prepared from neonatal animals which had become mitotically quiescent, whereas Beuche \& Friede utilized mature, fully differentiated Schwann cells which had produced a myelin sheath. In addition, the model used by Beuche \& Friede only generated about $20 \%$ of the increase in cell density observed during in vivo Wallerian degeneration. A factor may be required for Schwann cell phagocytosis and proliferation which is present in our culture conditions but absent in the model of Beuche \& Friede. Alternatively macrophages may be present in our cultures which activate the Schwann cells to phagocytose the myelin. In any case, we agree with the conclusion of Beuche \& Friede that Wallerian degeneration is more intricate than previously thought and that further work is needed to clarify the molecular dynamics involved in the process.

The fluorescence surface phenomenon seemed specific for axolemma as myelin and liver microsomes did not interact with the Schwann cells in a similar manner. The suggestion has been made that Schwann cell proliferation during development may be mediated by contact of the cells with the growing axons. Salzer et al. (1980a) showed that Schwann cell proliferation in vitro requires direct.contact with neurite preparations. Our data support the contention that direct axonal contact may facilitate Schwann cell profileration in development. Although some membrane fragments are endocytosed, the mitogenic signal of axolemma is not processed at the lysosomal level, and morphological evidence presented here suggests that the signal may be transduced at the cell surface.

Salzer \& Bunge (1980) suggested that the stimuli for in vivo Schwann cell proliferation during Wallerian degeneration and neural development may be different. The present 
study presents morphological evidence that the mitogenic signals of axolemma and myelin are transduced by separate mechanisms. This evidence is corroborated by biochemical studies which have demonstrated that the kinetics of axolemma and myelin-stimulated Schwann cell proliferation are also different; their dose-response curves and the rate at which they stimulate $\left[{ }^{3} \mathrm{H}\right]$ thymidine uptake into Schwann cells were found to be different by Yoshino et al. (1984). The demonstration of distinct mechanisms for the transduction of the mitogenic signals of axolemma and myelin may represent in vitro models for the proliferation of Schwann cells seen in degeneration and development. Efforts are presently being directed at identifying molecular events in the mechanisms of the transduction of the mitogenic signals. We have recently reported on the roles of calcium and cyclic AMP in the mediation of the mitogenic signals of axolemma and myelin (Meador-Woodruff et al., 1984).

\section{Acknowledgements}

This work was supported by Grants NS 10821 and NS 15408 from the United States Public Health Service. The authors thank Judy Kendrick and Rosa Bailey for secretarial assistance.

\section{References}

ASBURY, A. K. (1967) Schwann cell proliferation in developing mouse sciatic nerve. Journal of Cell Biology 34, 735-43.

BERNER, A., TORVIK, A. \& STENWIG, A. E. (1973) Origin of macrophages in traumatic lesions and Wallerian degeneration in peripheral nerves. Acta neuropathologica 25, 228-36.

BEUCHE, W. \& FRIEDE, R. L. (1984) The role of non-resident cells in Wallerian degeneration. Journal of Neurocytology 13, 767--96.

BIGbeE, J. W., CAlABRESE, V. P. \& DevRIES, G. H. (1985) Characterization of an antiserum against an axolemma-enriched fraction. Journal of Neuroimmunology 7, 221-9.

BRADFORD, M. M. (1976) A rapid and sensitive method for the quantitation of microgram quantities of protein utilizing the principle of protein-dye binding. Analytical Biochemistry 72, 248-54.

BRADLEY, W. G. \& ASBURY, A. K. (1970) Duration of synthesis phase in neurilemma cells in mouse sciatic nerve during degeneration. Experimental Neurology 26, 275-82.

BROCKES, J. P., FIELDS, K. L. \& RAFF, M. C. (1979) Studies on cultured rat Schwann cells. I. Establishment of purified populations from cultures or peripheral nerve. Brain Research 165, 105-18.

BROCKES, J. P., FRYXELL, K. J. \& LEMKE, G. E. (1981) Studies on cultured Schwann cells, the induction of myelin synthesis and the control of their proliferation by a new growth factor. Journal of Experimental Biology 95, 215-30.

DeVRIES, G. H., ANDERSON, M. G. \& JOHNSON, D. (1983a) Fractionation of isolated rat C.N.S. myelinated axons by sucrose density gradient centrifugation in a zonal rotor. Journal of Neurochemistry 40, 1709-17.

DevRIES, G. H., MATTHIEU, J. M., BENY, M., CHICHEPORTICHE, R., LAZDUNSKI, M. \& DOLIVO, M. (1978) Isolation and partial characterization of rat C.N.S. axolemma-enriched fractions. Brain Research 147, 339-52. 
DeVRIES, G. H., MINIER, L. N. \& LEWIS, B. L. (1983b) Further studies on the mitogenic response of cultured Schwann cells to rat C.N.S. axolemma-enriched fractions. Developmental Brain Research 9, 87-93.

DeVRIES, G. H., SALZER, J. L. \& BUNGE, R. P. (1982) Axolemma-enriched fractions isolated from P.N.S. and C.N.S. are mitogenic for cultured Schwann cells. Developmental Brain Research 3, 295-9.

EASTY, G. C. \& TROWELL, O. A. (1965) The uptake of fluorescence-labeled plasma protein by cells in organ culture. Experimental Cell Research 40, 224-32.

FIELDS, K. L. \& RAINE, C. S. (1982) Ultrastructure and immunocytochemistry of rat Schwann cells and fibroblasts in vitro. Journal of Neuroimmunology 2, 155-66.

FISHER, E. R. \& TURANO, A. (1963) Schwann cells in Wallerian degeneration. Archives of Pathology $75,517-27$.

FRIEDE, R. L. \& JOHNSTONE, M. A. (1967) Responses of thymidine labeling of nuclei in gray matter and nerve following sciatic transection. Acta neuropathologica 7, 218-31.

GLIMELIUS, B., WESTERMARK, B. \& WASTESON, A. (1977) Ammonium ion interferes with the lysosomal degradation of glycosaminoglycans in cultures of human glial cells. Experimental Cell Research 108, 23-30.

HOLTZMAN, E. \& NOVIKOFF, A. B. (1965) Lysosomes in the rat sciatic nerve following crush. Journal of Cell Biology 27, 651-69.

MARTIN, J. R. \& WEBSTER, H. DeF. (1973) Mitotic Schwann cells in developing nerve, their changes in shape, fine structure, and axon relationships. Developmental Biology 32, 417-31.

MEADOR-WOODRUFF, J., LEWIS, B. L. \& DevRIES, G. H. (1984) Cyclic AMP and calcium as potential mediators of axolemma and myelin-enriched fraction stimulation of cultured Schwann cells. Biochemical and Biophysical Research Communications 122, 373-80.

NEVILLE, D. M. (1968) Isolation of an organ specific protein antigen from cell surface membrane of rat liver. Biochemia et Biophysica Acta 154, 540-52.

PEARSE, A. G. E. (1980) Histochemistry. Theoretical and Applied, Vol. I. pp 159-252. New York, Churchill Livingstone, Inc.

POOLE, B. \& OHKUMA, S. (1981) Effect of weak bases on the intralysosomal pH in mouse peritoneal macrophages. Journal of Cell Biology 90, 665-9.

RAFF, M. C., ABNEY, E., BROCKES, J. P. \& HORNBY-SMITH, A. (1978a) Schwann cell growth factors. Cell 15, 813-22.

RAFF, M. C., HORNBY-SMITH, A. \& BROCKES, J. P. (1978b) Cyclic AMP is a mitogenic signal for cultured rat Schwann cells. Nature 273, 672-3.

RAINE, C. S. (1977) Morphological aspects of myelin and myelination. In Myelin (edited by P. MORELL), pp 1-49. New York, Plenum Press.

RHODES, J. M. \& LIND, I. (1968) Antigen uptake in vivo by peritoneal macrophages from normal mice, and those undergoing primary or secondary responses. Immunology 14, 511-25.

ROMINE, J. S., BRAY, G. M. \& AGUAYO, A. J. (1976) Schwann cell multiplication after crush injury of unmyelinated fibers. Archives of Neurology 33, 49-54.

ROTE, K. V. \& RECHSTEINER, M. (1983) Degradation of microinjected proteins, effects of lysosomotropic agents and inhibitors of autophagy. Journal of Cell Physiology 116, 103-10.

SALZER, J. L. \& BUNGE, R. P. (1980) Studies of Schwann cell proliferation. I. An analysis in tissue culture of proliferation during development, Wallerian degeneration, and direct injury. Journal of Cell Biology 84, 739-52.

SALZER, J. L., BUNGE, R. P. \& GLASER, L. (1980a) Studies of Schwann cell proliferation. III. Evidence for the surface localization of the neurite mitogen. Journal of Cell Biology 84, 767-78.

SAlZER, J. L., WILliAMS, A. K., GLASER, L. \& BUNGE, R. P. (1980b) Studies of Schwann cell proliferation. II. Characterization of the stimulation and specificity of the response to a neurite membrane fraction. Journal of Cell Biology 84, 753-66. 
SANDVIG, K., OLSNES, S. \& PIHL, A. (1979) Inhibitory effect of ammonium chloride and chloroquine on the entry of the toxic lectin modeccin into HeLa cells. Biochemical and Biophysical Research Communications 90, 648-55.

SATINSKY, D., PEPE, F. A. \& LIU, C. N. (1964) The neurilemma cell in peripheral nerve degeneration and regeneration. Experimental Neurology 9, 441-51.

SEGLEN, P. O. (1975) Protein degradation in isolated rat hepatocytes is inhibited by ammonia. Biochemical and Biophysical Research Communications 66, 44-52.

SEGLEN, P. O. \& REITH, A. (1976) Ammonia inhibition of protein degradation in isolated rat hepatocytes. Experimental Cell Research 100, 276-80.

TERRY, L. C., BRAY, G. M. \& AGUAYO, A. J. (1974) Schwann cell multiplication in developing rat unmyelinated nerves - a radioautographic study. Brain Research 69, 144-8.

THOMAS, P. K. (1970) The cellular response to nerve injury. 3. The effect of repeated crush injuries. Journal of Anatomy 106, 463-70.

TIETZE, C., SCHLESINGER, P. \& STAHL, P. (1980) Chloroquine and ammonium ion inhibit receptor-mediated endocytosis of mannose-glycoconjugates by macrophages, apparent inhibition of receptor recycling. Biochemical and Biophysical Research Communications 93, 1-8.

WILD, A. E. (1970) Protein transmission across the rabbit foetal membranes. Journal of Embryology and Experimental Morphology 24, 313-30.

WILD, A. E. (1973) Fluorescent protein tracing in the study of endocytosis. In Lysosomes in Biology and Pathology, Vol. 3 (edited by DINGLE, J. T.), pp 511-26 Amsterdam, North-Holland Publishing Company..

WOOD, P. M. \& BUNGE, R. P. (1975) Evidence that sensory axons are mitogenic for Schwann cells. Nature 256, 662-4.

YOSHINO, J., DINNEEN, M. P., LEWIS, B. L., MEADOR-WOODRUFF, J. H., \& DeVRIES, G. H. (1984) Differential proliferative responses of cultured Schwann cells to axolemma and myelin-enriched fractions I. Biochemical studies. Journal of Cell Biology 99, 2309-13. 